\title{
DIAGNOSA KERUSAKAN BANTALAN BOLA MENGGUNAKAN METODE SUPPORT VECTOR MACHINE
}

\author{
Muhammad Fathurrohman ${ }^{1}$, R. Lulus Lambang G. $\mathbf{H}^{1}$, Didik Djoko Susilo ${ }^{1}$ \\ ${ }^{1}$ Teknik Mesin - Universitas Sebelas Maret
}

\begin{tabular}{|c|c|}
\hline Keywords: & Abstract : \\
\hline $\begin{array}{l}\text { fault diagnosis, feature extraction, } \\
\text { Principal Component Analysis } \\
(P C A), \text { Support Vector Machine } \\
(S V M), \text { ball bearing }\end{array}$ & $\begin{array}{l}\text { Bearings are the critical part of any rotating machine. The } \\
\text { catastrophic failure of the bearing can lead to fatal and harmful to the } \\
\text { operation of the machine. Therefore, predictive maintenance based on } \\
\text { condition monitoring of bearing is very important. The objective of this } \\
\text { research is to apply Support Vector Machine (SVM) method for fault } \\
\text { diagnosis of the ball bearing. The research was carried out at the bearing } \\
\text { test rig. Four types of ball bearing condition, such as normal, inner race } \\
\text { defect, ball defect, and outer race defect were measured of the vibration } \\
\text { signals using data acquisition with a sampling frequency of } 20 \mathrm{kHz} \text { at the } \\
\text { constant speed of } 1400 \text { RPM. Various features were extracted from } \\
\text { vibration signals in time domain, such as RMS, variance, standard } \\
\text { deviation, crest factor, shape factor, skewness, kurtosis, log energy } \\
\text { entropy and sure entropy. PCA transformation was employed to reduce } \\
\text { the dimension offeature extracted data. SVM classification problems were } \\
\text { solved using MATLAB 2016a. The results showed that the application of } \\
\text { RBF kernel function with the C parameter =1 was the best configuration. } \\
\text { The training model accuracy was } 98.93 \% \text { and the testing accuracy of SVM } \\
\text { was } 97.5 \% \text {. Finally, the research results show that the SVMclassification } \\
\text { method can be used to diagnose the fault condition of the ball bearing.. }\end{array}$ \\
\hline
\end{tabular}

\section{PENDAHULUAN}

Mesin-mesin rotasi (rotating machinery) merupakan mesin yang banyak dijumpai dalam dunia industri dan mempunyai peran penting dalam proses industri (Ramali, 2012). Mesin rotasi terdiri dari elemen-elemen mesin, seperti poros, roda gigi, engkol, bantalan maupun elemen lainnya, dimana komponenkomponen tersebut akan mengalami kegagalan, baik karena masa pakai alat atau karena komponen tersebut mengalami kerusakan, sehingga menyebabkan terhambatnya proses produksi (Sitohang, 2014). Bantalan gelinding (ball bearing) merupakan salah satu komponen penting pada mesin dimana kegagalan pada komponen bantalan merupakan salah satu penyebab utama kerusakan pada mesin (Ullu, 2013). Oleh karena itu, diagnosis kerusakan bantalan bola perlu dilakukan untuk mencegah kerusakan serius pada mesin. Analisis yang tepat dalam menentukan kondisi suatu mesin akan berdampak pada peningkatan efisiensi dan produktivitas perusahaan (Kappaganthu, dkk., 2009).

Teknik condition monitoring diperkenalkan sebagai suatu metode diagnosis yang mampu mengidentifikasi kondisi mesin ketika terjadi penyimpangan dari kondisi normal. Berbagai metode diagnosis untuk analisis kondisi mesin terus dikembangkan, baik melalui analisis kondisi dengan dasar pengamatan karakteristik sinyal getaran, maupun pendekatan berbasis machine learning (Wong, dkk., 2013).

Pada beberapa dekade terakhir metode pemantauan kondisi berbasis machine learning, seperti neural network, fuzzy logic, genetic algorithm dan support vector machine banyak diterapkan untuk aplikasi diagnosis kegagalan komponen mesin. Support vector machine (SVM) adalah metode pembelajaran statistik yang memiliki keunggulan tersendiri pada aplikasi permasalahan klasifikasi. Dalam hal generalisasi model, dapat dikatakan bahwa metode klasifikasi SVM lebih baik daripada metode neural network (Estilaf dan Fatemi, 2014).

Metode pemantauan kondisi berbasis machine learning dapat diaplikasikan untuk diagnosis kegagalan pada bantalan bola. Metode penelitian didasarkan pada metode wavelet packet transform (WPT) untuk preprocessing sinyal, ekstraksi fitur, principal component analysis (PCA) untuk mereduksi fitur dan support vector machine (SVM) untuk mengklasifikasikan kerusakan pada komponen bantalan. Metode klasifikasi SVM diterapkan dengan 
\begin{tabular}{l|l} 
Mekanika: Majalah Ilmiah Mekanika & 15 \\
Volume 18 Nomor 1 Maret 2019 &
\end{tabular}

optimasi nilai parameter menggunakan particle swarm optimization with passive congregation (PSOPC). Hasil klasifikasi menunjukkan efektivitas dan akurasi yang baik, sehingga metode SVM layak digunakan untuk mendiagnosis kegagalan pada bantalan bola (Thelaidjia, dkk., 2016).

Pengaplikasian metode machine learning, yaitu support vector machine (SVM) dan Artificial Neural Network (ANN) untuk diagnosis kerusakan bantalan bola dilakukan dengan mempertimbangkan jenis fitur yang digunakan sebagai data input pada machine learning. Nilai fitur didapatkan dari ekstraksi fitur data mentah sinyal getaran yang terdiri dari fitur-fitur statistik dan beberapa fitur entropy. Fitur-fitur tersebut diuji sensitivitasnya terhadap variasi tingkat kerusakan pada komponen bantalan untuk menentukan fitur yang tepat, yaitu fitur yang dapat mereppresentasikan kondisi pada bantalan bola. Hasil pengujian menunjukkan fitur

statistik, seperti skewness, kurtosis, root mean square (rms), standar deviasi, dan crest factor dan fitur entropy seperti, log energy entropy, dan sure entropy dapat diterapkan untuk mendiagnosis kerusakan pada bantalan bola secara efektif dan tepat (Sharma, dkk., 2014).

Pada penelitian ini, metode SVM diaplikasikan untuk mendiagnosis kerusakan pada bantalan bola. Beberapa kondisi kerusakan pada bantalan bola akan diklasifikasikan dengan proses pembelajaran secara terarah (supervised learning).

\section{METODOLOGI PENELITIAN Ekstraksi Fitur}

Ekstraksi fitur adalah metode analisis data yang diterapkan sebelum proses klasifikasi. Analisis data merupakan tahapan penting pada diagnosis kegagalan pada mesin yang mengaplikasikan metode berbasis klasifikasi pengenalan pola (pattern recognition). Tujuan ekstraksi fitur adalah untuk memperoleh informasi penting dari suatu sinyal menggunakan transformasi yang sederhana dan efektif.

Beberapa fitur parameter statistik dinilai cukup signifikan untuk analisis sinyal getaran domain waktu. Kondisi kerusakan mesin dapat dibedakan menggunakan representasi kuantitatif ciri sinyal domain waktu. Parameter statistik tersebut antara lain sebagai berikut.

1. Root Mean Square (RMS)

RMS didefinisikan sebagai akar kuadrat dari rata-rata nilai kuadrat dari bentuk gelombang sinyal getaran yang dirumuskan sebagai berikut:

$R M S=\sqrt{\frac{1}{N} \sum_{i=1}^{N} X_{i}^{2}}$

2. Standar Deviasi $(\sigma)$
Standar deviasi menunjukkan tingkat energi atau daya yang terkandung dalam sinyal getaran yang dihitung dengan rumus:

$\sigma=\sqrt{\frac{m \sum_{i=1}^{N} X_{i}{ }^{2}-\left(\sum_{i=1}^{N} X_{i}\right)^{2}}{N(N-1)}}$

3. Variance

Variance adalah ukuran yang menunjukkan seberapa jauh kumpulan data tersebar yang dihitung dengan rumus:

Variance $=\frac{n \sum_{i=1}^{N} X_{i}^{2}-\left(\sum_{i=1}^{N} X_{i}\right)^{2}}{N(N-1)}$

4. Crest-Factor

Crest factor didefinisikan sebagai rasio nilai maksimal dari sinyal input terhadap nilai RMS yang dapat dicari dengan persamaan berikut:

$C F=\frac{X_{\max }}{R M S}$

Dengan $X_{\text {max }}$ adalah nilai maksimum dari $X_{i}$.

5. Shape-Factor

Shape factor didefinisikan sebagai rasio antara nilai RMS dengan nilai rata-rata. nilai shape factor (SF) dapat dicari dengan persamaan:

$S F=\frac{R M S}{\mu}$

Dengan $\mu=\frac{1}{N} \sum_{i=1}^{N} X_{i}$

6. Kurtosis

Kurtosis menunjukkan kelancipan dan kedataran relatif sebuah distribusi dibanding distribusi normal sinyal. Nilai kurtosis (K) dapat diperoleh melalui persamaan berikut:

$K=\frac{\frac{1}{N} \sum_{i=1}^{N}\left(X_{i}-\mu\right)^{4}}{\sigma^{4}}$

7. Skewness

Skewness menggambarkan derajat kesimetrisan distribusi disekitar daerah rata-ratanya. Nilai skewness (sk), diperoleh dengan persamaan:

$$
s k=\frac{\frac{1}{N} \sum_{i=1}^{N}\left(X_{i}-\mu\right)^{3}}{\sigma^{3}}
$$

Selain parameter fitur-fitur statistik, nilai entropy juga dapat mendefinisikan secara kuantitatif kondisi suatu mesin. Nilai entropy merupakan ukuran kuantitatif yang menunjukkan ketidakteraturan suatu sistem. Beberapa nilai entropy yang dapat digunakan antara lain:

1. Log energy entropy $=\sum_{i=1}^{N} \log \left(x_{i}^{2}\right)$

2. Sure entropy $=N-\#\left\{i\right.$ sehingga $\left.\left|x_{i}\right| \leq p\right\}$

$$
+\sum_{i=1}^{N} \min \left(x_{i}^{2}, p^{2}\right)
$$

\section{Principal Component Analysis (PCA)}

Principal Component Analysis (PCA) merupakan suatu teknik statistik untuk mengubah satu set variabel data asli yang saling berkorelasi satu dengan yang lainnya menjadi satu set variabel data baru yang saling bebas (tidak saling berkorelasi) yang 
mewakili sebagian besar informasi dari set variabel data asli dengan cara mentransformasi linear variabel data asli kedalam sistem koordinat baru. PCA bermanfaat untuk mereduksi dimensi suatu data tanpa mengurangi informasi karakteristik data tersebut. Variabel hasil dari reduksi tersebut dinamakan principal component (PC). Adapun algoritma PCA secara umum sebagai berikut :

1. Hitung matriks kovarian dengan menggunakan persamaan.

$$
\operatorname{cov}(X, Y)=\frac{\sum_{i=1}^{n}\left(X_{i}-X\right)\left(Y_{i}-Y\right)}{(n-1)}
$$

2. Hitung nilai eigen dengan menyelesaikan persamaan.

$$
(A-\lambda I)=0
$$

3. Hitung vektor eigen dengan menyelesaikan persamaan.

$$
(A-\lambda I)[X]=[0]
$$

4. Tentukan variabel baru (principal component) dengan mengalikan variabel asli dengan matriks vektor eigen.

Sedangkan besar varians yang dapat dijelaskan oleh variabel baru tergantung kontribusi pi, dari masing-masing nilai eigen yang dihitung dengan persamaan.

$$
p i=\frac{\lambda_{i}}{\sum_{j=I}^{n}\left(\lambda_{j}\right)}
$$

Salah satu cara untuk menentukan jumlah PC yang akan digunakan untuk analisis selanjutnya adalah dengan melihat total varians kumulatif dengan syarat persentase lebih dari $80 \%$.

\section{Support Vector Machine (SVM)}

Konsep dasar SVM dapat dijelaskan secara sederhana sebagai usaha mencari hyperplane terbaik untuk mengklasifikasikan dua buah kelas pada input space. Secara intuitif hyperplane terbaik didapatkan dengan mencari bidang pemisah dengan jarak margin maksimal. Margin dapat didefinisikan sebagai jarak antara hyperplane dengan data yang paling dekat dengan hyperplane dari masing-masing kelas. Data yang terdekat dengan hyperplane yang digunakan untuk mendefinisikan margin disebut sebagai support vector. Usaha untuk menemukan hyperplane terbaik ini merupakan inti dari proses pembelajaran SVM. Ilustrasi penjelasan konsep dasar klasifikasi SVM tersebut dapat dilihat pada Gambar 1 berikut.

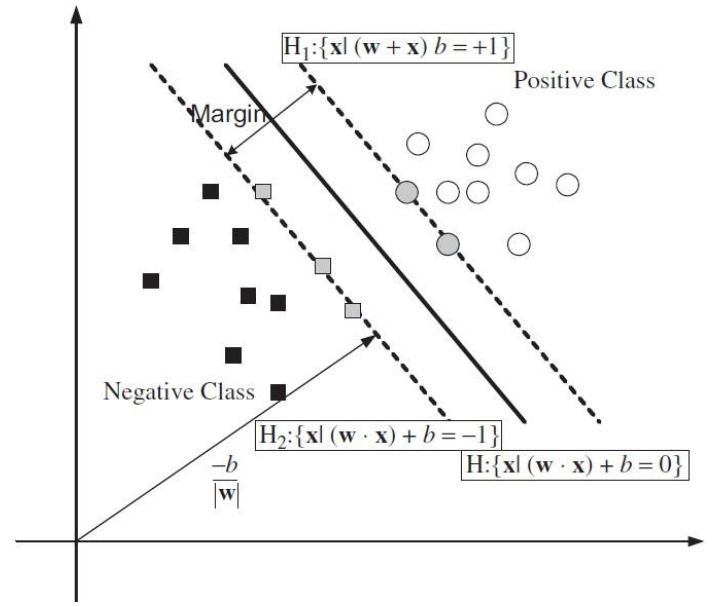

Gambar 1. Konsep Klasifikasi SVM (Widodo, 2009)

Pada Gambar diatas dua kelas dipisahkan oleh dua bidang pembatas sejajar. Bidang pembatas pertama membatasi kelas pertama sedangkan bidang kedua membatasi kelas kedua, sehingga diperoleh:

$$
\begin{gathered}
x_{i} \cdot w+b \geq+1 \text { untuk xi }=+1 \\
x_{i} \cdot w+b \leq-1 \text { untuk xi }=-1
\end{gathered}
$$

Dengan $w$ adalah normal bidang dan $b$ adalah posisi bidang relatif terhadap pusat kooordinat. Nilai margin (jarak) antara bidang pembatas (berdasarkan rumus jarak ke garis pusat) adalah $\frac{1-b-(-1-b)}{w}=\frac{2}{|w|}$ Nilai margin ini dimaksimalkan dengan tetap memenuhi persamaan (15). Dengan mengalikan $b$ dan $w$ dengan sebuah konstanta, akan dihasilkan nilai margin yang dikalikan dengan konstanta yang sama. Selain itu, karena memaksimalkan $1 /|w|$ sama dengan meminimumkan $|w|^{2}$ dan jika persamaan (15) dipresentasikan ke dalam pertidaksamaan $y_{i}\left(x_{i} \cdot w+b\right)-1 \geq 0$. Maka pencarian bidang pemisah terbaik dengan nilai margin terbesar dapat dirumuskan menjadi masalah optimasi konstrain, yaitu :

$$
\begin{aligned}
& \min \frac{1}{2}|w|^{2} \\
& \text { s,t } y_{i}\left(x_{i} \cdot w+b\right)-1 \geq 0
\end{aligned}
$$

Pada kasus dimana ada beberapa data yang tercampur dan dimungkinkan tidak bisa dipisahkan oleh hyperplane, maka rumus SVM diatas perlu dimodifikasi karena konstrain pada persamaan tersebut tidak dapat terpenuhi, sehingga optimasi tidak dapat dilakukan. Penyelesaian pada permasalahan ini adalah dengan memodifikasi persamaan (15) dengan menambahkan variabel slack $\left(\xi_{i}\right)$, sehingga persamaan tersebut menjadi:

$$
\begin{aligned}
& x_{i} \cdot w+b \geq 1-\xi_{i} \text { untuk } y_{i}=+1 \\
& x_{i} \cdot w+b \geq-1+\xi_{i} \text { untuk } y_{i}=-1
\end{aligned}
$$




\section{Mekanika: Majalah Ilmiah Mekanika 17 Volume 18 Nomor 1 Maret 2019}

Sehingga formula permasalahan optimasi konstrain pada persamaan (16) menjadi:

$$
\begin{aligned}
& \min \frac{1}{2}|w|^{2}+C\left(\sum_{i=1}^{n} \xi_{i}\right. \\
& \text { s.t } y_{i}\left(x_{i} . w+b\right) \geq 1-\xi_{i}, \xi_{i} \geq 0
\end{aligned}
$$

Dimana $\xi_{-}$i adalah jarak antara margin dengan data $\mathrm{x} \_\mathrm{i}$ yang terletak di sisi yang salah dari bidang pemisah.

Variabel $\mathrm{C}$ adalah parameter yang menentukan besar penalti kesalahan yang diberikan akibat kesalahan klasifikasi data yang nilainya ditentukan oleh pengguna (user). Nilai $\mathrm{C}$ yang besar akan menghasilkan pengklasifikasian data pelatihan dengan benar, sedangkan nilai $\mathrm{C}$ yang kecil menghasilkan hyperplane yang lebih fleksibel untuk memaksimalkan bidang pemisah.

Solusi pada permasalahan tersebut dapat diselesaikan menggunaan persamaan lagrange. Sehingga setelah solusi permasalahan tersebut ditemukan, maka penentuan kelas dari data pengujian $\mathrm{x}$ dapat ditentukan berdasarkan nilai fungsi keputusan: $f\left(x_{d}\right)=\sum_{i=0}^{n s} \alpha_{i} y_{i} x_{i} x_{d}+b$

$x_{i}$ adalah support vector, $\mathrm{ns}=$ jumlah support vector dan $x_{d}$ adalah data yang akan diklasifikasi.

Metode SVM juga dapat digunakan pada kasus data yang tidak terpisahkan secara linear. Data yang akan diklasifikasikan ditransformasi dari dimensi ruang input ke dalam dimensi ruang fitur sehingga pemisahan secara linear dapat dilakukan. Fungsi transformasi diterapkan dengan memanfaatkan fungsi kernel, yaitu sebuah fungsi yang mengembalikan dot product pemetaan pada dimensi ruang fitur dari dimensi data asli. Sehingga fungsi keputusan yang dihasilkan menjadi:

$$
f\left(x_{\dot{d}}\right)=\sum_{i=1}^{n s} \alpha_{i} y_{i} K\left(x_{i}, x_{\dot{d}}\right)+b
$$

Beberapa fungsi kernel yang umum digunakan dinyatakan pada Tabel 1 berikut:

Tabel 1. Rumus Fungsi Kernel

\begin{tabular}{|l|l|}
\hline \multicolumn{1}{|c|}{ Jenis Kernel } & \multicolumn{1}{c|}{$K\left(x_{i} x\right)$} \\
\hline Linear & $x_{i}^{T} x$ \\
\hline Polinomial & $\left(\gamma \cdot x_{i}^{T} x+r\right)^{p}, \gamma>0$ \\
\hline $\begin{array}{l}\text { Radial Basis Function } \\
\text { (RBF) }\end{array}$ & $\exp \left(-\gamma\left|x_{i}-x\right|^{2}\right), \gamma>0$ \\
\hline
\end{tabular}

Padá däsarnya, SVM hanya dapat digunakān untuk mengklasifikasikan data pada dua kelas (klasifikasi biner). Sehingga, diperlukan pendekatan metode multiclass SVM. Metode yang paling umum diterapkan adalah dengan cara menggabungkan beberapa SVM biner, yaitu pendekatan dengan metode one-against-all (OAA) ataupun one-against-one (OAO).

\section{METODE PENELITIAN}

Alat dan Bahan

Pengujian dilakukan pada Rig Pengujian Bantalan sebagaimana ditunjukkan pada Gambar 2. Rangkaian alat tersebut terdiri dari motor listrik 3 fasa $1 \mathrm{HP}$, kopling, poros, bantalan penumpu, housing bantalan uji, dan struktur penyangga. Bantalan bola yang diuji adalah NACHI tipe 6201-2NSE9 yang divariasikan dengan kondisi normal, cacat lintasan dalam, cacat pada bola, dan cacat lintasan luar. Pemberian cacat buatan pada komponen bantalan bola menggunakan proses EDM dengan diameter elektroda $1 \mathrm{~mm}$ dan 1,5 mm untuk tiap variasi lokasi cacat. Variasi tiap kondisi bantalan bola diperlihatkan pada gambar 3 .

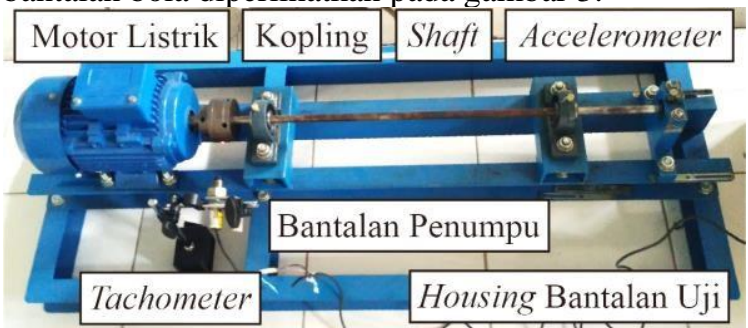

Gambar 2. Kıg Pengujan Bantalan

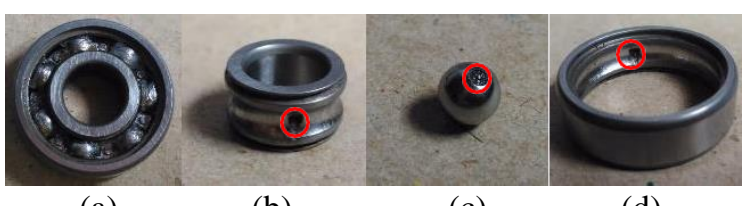

(a)

(b)

(c)

(d)

Gambar 3. Bantalan bola pengujian: (a) Normal; (b) Cacat lintasan dalam; (c) Cacat pada bola; (d) Cacat lintasan luar.

\section{Perekaman Sinyal Getaran}

Pengambilan data sinyal getaran bantalan bola diatur pada kecepatan motor 1400 RPM konstan tanpa pembebanan. Pengukuran sinyal menggunakan sensor accelerometer model 352C33 PCB Piezotronics dengan arah pengukuran radial vertikal. Sistem akuisisi data menggunakan perangkat Dewesoft ${ }^{\circledR}$ dengan frekuensi sampling $20000 \mathrm{~Hz}$.

\section{Ekstraksi dan Reduksi Fitur}

Data sinyal getaran hasil pengukuran diambil sejumlah 100 data set untuk tiap kondisi bantalan, sehingga total 400 data set yang kemudian dibagi 2, yaitu: 280 data training dan 120 data testing. Tiap sampel data set terdiri dari 8192 data points sinyal getaran yang kemudian diekstraksi menjadi nilai yang lebih sederhana menggunakan parameter statistik dan entropy, yaitu: yaitu RMS, variance, standar deviasi, 


\section{Mekanika: Majalah Ilmiah Mekanika 18 Volume 18 Nomor 1 Maret 2019}

crest factor, shape-factor, skewness, kurtosis, log energy entropy, dan sure entropy.

Metode transformasi PCA diterapkan untuk mereduksi jumlah fitur hasil ekstraksi. Berdasarkan hasil reduksi fitur PCA, jumlah fitur yang digunakan sebagai input SVM adalah 2 fitur PC (principal components) dengan nilai varians terbesar.

\section{Klasifikasi SVM}

Klasifikasi SVM diselesaikan menggunakan perangkat lunak MATLAB 2016a Toolbox SVM. Proses klasifikasi SVM dilakukan melalui 2 tahapan, yaitu pelatihan dan pengujian. Proses pelatihan SVM dilakukan menggunakan data training untuk mengklasifikasikan 4 kondisi bantalan berbeda. Model pengklasifikasi diperoleh dari hasil pelatihan SVM melalui tahap pemilihan fungsi kernel dan penentuan nilai parameter C. Fungsi kernel yang diujikan pada SVM, yaitu: Linear, RBF (Radial Basis Function), dan Polinomial.

Model klasifikasi SVM yang telah diperoleh kemudian diuji menggunakan data testing untuk menjamin generalisasi model dengan cara membandingkan hasil akurasi antara model dengan hasil pengujian klasifikasi SVM.

\section{HASIL DAN PEMBAHASAN}

Pengaplikasian metode klasifikasi SVM untuk diagnosis kerusakan bantalan pada kasus ini merupakan permasalahan dengan jumlah kelas lebih dari dua, serta karakteristik data yang tidak dapat dipisahkan secara linear. Proses klasifikasi SVM diselesaikan menggunakan program MATLAB 2016a Toolbox Statistics and Machine Learning. Metode One-Against-One (OAO) diterapkan pada kasus multiclass SVM. Fungsi kernel diterapkan pada pembelajaran SVM sebagai solusi untuk kasus data yang tidak dapat dipisahkan secara linear.

\section{Penentuan Fungsi Kernel}

Pembelajaran SVM untuk menetapkan model klasifikasi mencakup 2 pekerjaan, yaitu memilih fungsi kernel dan menetapkan nilai parameter C (error penalty) (Chin, 1998). Untuk memilih fungsi kernel yang sesuai, 3 jenis fungsi kernel diterapkan pada proses pembelajaran SVM dan dibandingkan akurasi masing-masing penggunaan kernel tersebut. Perbandingan hasil akurasi tersebut ditunjukkan pada Tabel 2 berikut.

Tabel 2 Hasil Penerapan Fungsi Kernel pada SVM

\begin{tabular}{|c|l|c|c|}
\hline No & \multicolumn{1}{|c|}{$\begin{array}{c}\text { Fungsi } \\
\text { Kernel }\end{array}$} & $\begin{array}{c}\text { Akurasi } \\
\text { Model }\end{array}$ & $\begin{array}{c}\text { Akurasi } \\
\text { Pengujian }\end{array}$ \\
\hline $\mathbf{1}$ & Linear & $85,00 \%$ & $84,17 \%$ \\
\hline
\end{tabular}

\begin{tabular}{|c|l|c|c|}
\hline $\mathbf{2}$ & $\mathbf{R B F}$ & $\mathbf{9 8 , 9 3 \%}$ & $\mathbf{9 7 , 5 0 \%}$ \\
\hline $\mathbf{3}$ & Polinomial & $98,57 \%$ & $96,67 \%$ \\
\hline
\end{tabular}

Berdasarkan hasil yang ditunjukkan pada Tabel 2 dapat diketahui bahwa pada penerapan fungsi kernel $\mathrm{RBF}$ dan polinomial menunjukkan tingkat akurasi yang hampir sama, dimana akurasi pelatihan diperoleh berturut-turut $98,93 \%$ dan 98,57\%. Perbandingan hasil pengujian model SVM juga menunjukkan akurasi yang hampir sama, namun penerapan kernel RBF sedikit lebih baik dengan akurasi 97,5\%. Hasil yang kurang baik ditunjukkan pada penerapan kernel linear.

Berdasarkan hasil pembelajaran SVM tersebut, kernel RBF ditetapkan sebagai fungsi kernel yang paling tepat. Pemilihan tersebut didasarkan pada hasil akurasi pelatihan dan pengujian yang paling tinggi dibandingkan fungsi kernel yang lain. Meskipun pada penerapan fungsi kernel polinomial hasil akurasi yang ditunjukkan juga hampir sama, namun fungsi kernel RBF lebih dipilih karena cenderung lebih stabil serta memerlukan input parameter yang lebih sedikit (Pöyhönen, 2004).

\section{Penentuan Parameter C (error penalty)}

Parameter $\mathrm{C}$ disebut juga dengan penalti kesalahan, dimana hal ini berhubungan dengan trade-off antara maksimalisasi batas margin dan akurasi model klasifikasi selama pelatihan (Chin, 1998). Penentuan nilai parameter $\mathrm{C}$ yang tepat perlu dilakukan agar didapatkan model SVM dengan hasil optimal.

Penentuan nilai parameter $\mathrm{C}$ dilakukan dengan memvariasikan 4 nilai parameter $\mathrm{C}(0,1 ; 1 ; 10 ; 100)$ untuk mencari setting nilai dengan hasil yang paling optimal. Hasil pembelajaran SVM dengan variasi parameter $\mathrm{C}$ tersebut ditunjukkan pada Tabel 3.

Tabel 3. Hasil Pengaturan Variasi Parameter C

\begin{tabular}{|c|c|c|c|c|}
\hline No & C & $\begin{array}{c}\text { Free } \\
\text { SV }\end{array}$ & $\begin{array}{c}\text { Akurasi } \\
\text { Model }\end{array}$ & $\begin{array}{c}\text { Akurasi } \\
\text { Pengujian }\end{array}$ \\
\hline $\mathbf{1}$ & 100 & 91 & $98,57 \%$ & $96,67 \%$ \\
\hline $\mathbf{2}$ & 10 & 94 & $98,21 \%$ & $96,67 \%$ \\
\hline $\mathbf{3}$ & $\mathbf{1}$ & $\mathbf{9 1}$ & $\mathbf{9 8 , 9 3 \%}$ & $\mathbf{9 7 , 5 0 \%}$ \\
\hline $\mathbf{4}$ & 0,1 & 48 & $97,14 \%$ & $95,83 \%$ \\
\hline \multicolumn{5}{|c|}{ Berdasarkan pada Tabel 3 tersebut, akuras } \\
\hline
\end{tabular}
pelatihan tertinggi diperoleh pada nilai parameter $\mathrm{C}=1$ dengan akurasi 98,93\%, sedangkan akurasi pelatihan terendah didapatkan pada nilai parameter $\mathrm{C}=0,1$ dengan akurasi 97,14\%. Hasil akurasi pengujian pada nilai $\mathrm{C}=1$ juga menunjukkan hasil yang tertinggi, yaitu $97,5 \%$ dibandingkan dengan pengaturan nilai parameter $\mathrm{C}$ yang lain. Berdasarkan hubungan tradeoff nilai parameter $\mathrm{C}$, seharusnya semakin besar 


\section{Mekanika: Majalah Ilmiah Mekanika Volume 18 Nomor 1 Maret 2019}

penalti kesalahan yang diberikan, maka nilai akurasi pelatihan akan semakin meningkat. Namun, pada hasil pembelajaran ini pada nilai parameter $\mathrm{C}=10$ dan $\mathrm{C}=100$ menunjukkan penurunan akurasi pelatihan. Hal ini disebabkan adanya data antar kelas yang tercampur atau jaraknya yang sangat berdekatan.

Jumlah data training yang ditetapkan sebagai support vectors (SV) dapat dijadikan sebagai acuan tingkat generalisasi suatu model SVM, dimana dengan jumlah unbounded SV yang kecil cenderung memiliki generalisasi yang baik (Pöyhönen, 2004). Berdasarkan pada Tabel 3 tersebut, hasil pembelajaran untuk semua variasi nilai parameter $\mathrm{C}$ menunjukkan jumlah unbounded SV yang relatif kecil dibandingkan dengan jumlah total data training untuk pelatihan SVM, dimana perbandingan jumlahnya dibawah $50 \%$ untuk tiap variasi nilai parameter C. Sehingga, dapat disimpulkan bahwa pada keempat pengaturan nilai parameter $\mathrm{C}$ tersebut menunjukkan generalisasi model klasifikasi yang relatif baik.

\section{Hasil Pelatihan dan Pengujian SVM}

Pembelajaran SVM untuk mengklasifikasikan kerusakan bantalan bola pada penelitian ini ditetapkan menggunakan fungsi kernel RBF dengan nilai parameter $\mathrm{C}=1$. Proses pelatihan SVM menghasilkan model klasifikasi dengan akurasi 98,93\% dimana terdapat 3 data kesalahan klasifikasi. Plot model hasil pelatihan SVM tersebut ditunjukkan pada Gambar 4.

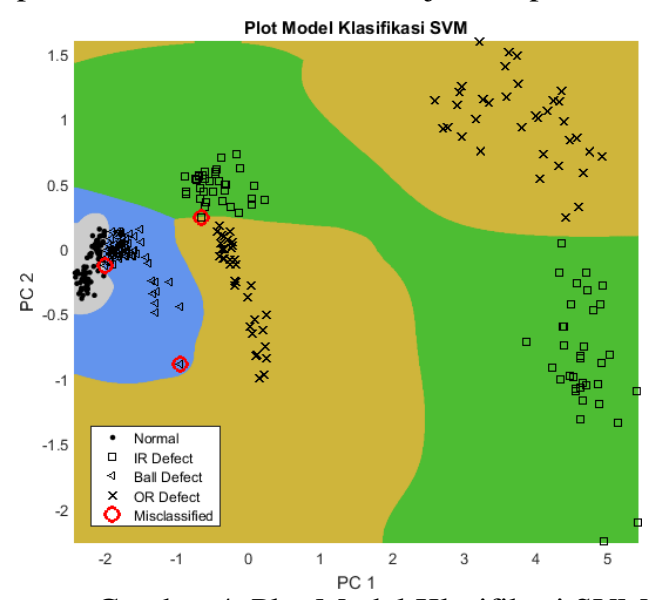

Gambar 4. Plot Model Klasifikasi SVM

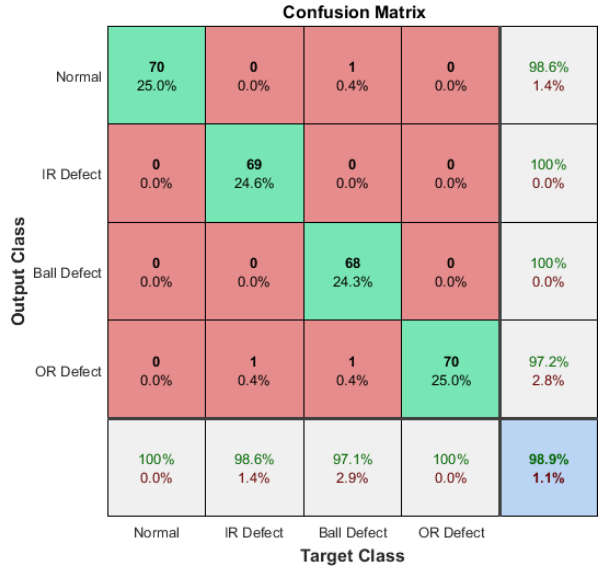

Gambar 5. Diagram Confussion Matrix Pelatihan

Berdasarkan diagram confussion matrix pada Gambar 5, terdapat 2 data yang seharusnya pada kelas cacat pada bola, tetapi salah diklasifikasikan ke dalam kelas normal dan cacat lintasan luar. Sedangkan 1 data kelas cacat lintasan dalam salah diklasifikasikan ke dalam kelas cacat lintasan luar. Sehingga total terdapat 3 kesalahan klasifikasi yang menyebabkan error model SVM sebesar $1,1 \%$.

Pengujian model klasifikasi SVM dilakukan untuk menjamin kemampuan model dalam mendiagnosis kerusakan bantalan bola. Hasil pengujian menunjukkan tingkat akurasi yang tidak terpaut jauh dengan akurasi model dengan nilai $97,50 \%$. Berdasarkan plot data pengujian model SVM pada Gambar 6, terdapat 3 data dari total 120 data testing yang salah diklasifikasikan.

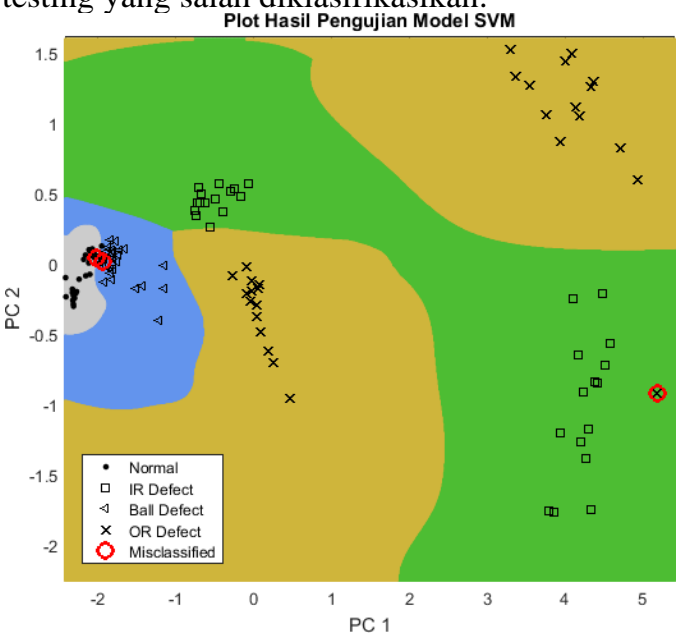

Gambar 6. Plot Pengujian Klasifikasi SVM 
\begin{tabular}{l|l} 
Mekanika: Majalah Ilmiah Mekanika & 20 \\
Volume 18 Nomor 1 Maret 2019 &
\end{tabular}

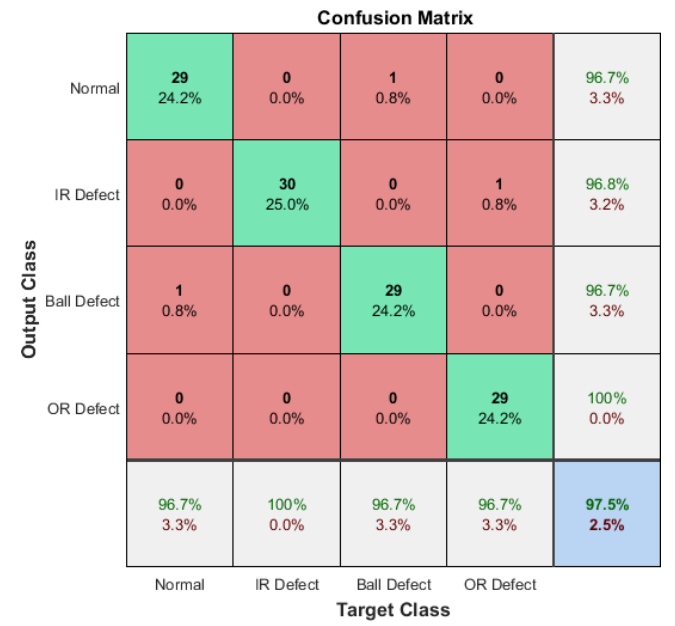

Gambar 7. Diagram Confussion Matrix Pengujian

Diagram confussion matrix pengujian klasifikasi SVM pada Gambar 7 menunjukkan data kelas normal dan cacat bola yang salah diklasifikasikan pada kelas sebaliknya, serta 1 data kelas cacat lintasan luar yang salah diklasifikasikan ke dalam kelas cacat lintasan dalam. Jika melihat plot sebaran data daerah masingmasing kelas, kesalahan klasifikasi pada data kelas cacat lintasan luar tersebut lebih kepada kesalahan pada data input, bukan pada model klasifikasi. Karena plot data yang salah diklasifikasikan tersebut berada jauh dari sebaran data kelas cacat lintasan luar dan lebih dekat ke sebaran data kelas cacat lintasan dalam. Namun, secara keseluruhan hasil pengujian model klasifikasi masih cukup baik yang ditunjukkan dengan nilai error pengujian sebesar $2,5 \%$.

\section{KESIMPULAN}

Pada penelitian ini, diagnosis kerusakan pada bantalan bola dengan mengaplikasikan metode Support Vector Machine (SVM) telah berhasil dilakukan. Berdasarkan hasil penelitian, model SVM yang diperoleh mampu mendiagnosis kerusakan pada bantalan bola dengan cara mengklasifikasikan 4 jenis kerusakan berbeda pada bantalan bola. Model SVM yang paling optimal didapatkan pada penerapan fungsi kernel RBF dengan pengaturan nilai error penalty (C) $=1$ yang ditunjukkan dengan akurasi pelatihan 98,93\%. Pengujian pada model SVM tersebut menunjukkan bahwa model yang terbentuk memiliki tingkat generalisasi yang baik, hal ini ditunjukkan dengan hasil akurasi pengujian $97,5 \%$.

\section{DAFTAR PUSTAKA}

[1] K. Aji, "Deteksi Kerusakan Bantalan Gelinding Pada Pompa Sentrifugal dengan Analisa Sinyal Getaran," Teknik Mesin Fakultas Teknik Universitas Sebelas Maret, Surakarta, vol. 7, no. $1,2007$.
[2] A. Bilosova dan J. Bilos, "Vibration Diagnostics, Investments in Education Development," Ostrava, 2012.

[3] BS ISO, ISO 13373-1:2002 "Condition monitoring and diagnostics of machines Vibration condition monitoring," British Standard Institution, 2002.

[4] K. K. Chin, "Support Vector Machines applied to Speech Pattern Classification," MPhil. Thesis, University of Cambridge, 1998.

[5] H. A. Estilaf dan S. M. J. R. Fatemi, "Bearing Fault Diagnosis of Electrical Machine base on Vibration Signal using Multi-Class Support Vector Machine," Indian J.Sci.Res., vol. 2, no. 1, pp. 46-53, 2014.

[6] C. W. Hsu dan C. J. Lin, "A comparison of methods for multiclass support vector machines," IEEE Transactions on Neural Networks, vol. 13, no. 2, pp. 415-425, 2002.

[7] Johnson dan Wichern, "Applied Multivariate Statistical Analysis," Edisi keenam, Pearson Prentice Hall, 2007.

[8] K. Kappaganthu, C. Nataraj, dan B. Samanta, "Model Based Bearing Fault Detection Using Support Vector Machines," Annual Conference of the Prognostics and Health Management Society, 2009.

[9] R. K. Mobley, "An Introduction to Predictive Maintenance, Elsevier Science," ButterworthHeinemann, 2002.

[10] S. Poyhonen, "Support Vector Machine based Classification in Condition Monitoring of Induction Motors," Helsinki University of Technology Control Engineering Laboratory, Report 141, 2004.

[11] D. Rahmanto, "Pengaruh Variasi Putaran terhadap Efektifitas Balancing Poros Fleksibel pada Proses Two-Plane Balancing," Teknik Mesin Fakultas Teknik Universitas Sebelas Maret, Surakarta, 2007.

[12] A. Ramali, B. Setiono, dan A. Hidayatno, "Identifikasi Kerusakan Mesin Berbasis Sinyal Getaran dengan Metode Fuzzy Logic," Teknik Elektro Fakultas Teknik Universitas Diponegoro, Semarang, 2012.

[13] K. Sembiring, "Tutorial Support Vector Machine," Teknik Informatika ITB, Bandung, 2007.

[14] A. Sharma, M. Amarnath, and P. K. Kankar, "Feature Extraction and Fault Severity 
Classification in Ball Bearings," J. of Vibration and Control, vol. 22, no. 1, pp. 1-17, 2014.

[15] N. T. Sitohang, E. Erinofiardi, dan A. F. Suryono, "Analisa Kegagalan Bantalan Skf 6005 pada Carrier Idler di PT. Pelabuhan Indonesia II (Persero) Cabang Bengkulu," Teknik Mesin Fakultas Teknik Universitas Bengkulu, Bengkulu, 2014.

[16] Suhardjono, "Analisis Sinyal Getaran untuk Menentukan Jenis dan Tingkat Kerusakan Bantalan Bola (Ball Bearing)," Teknik Mesin Institut Teknologi Sepuluh November, Surabaya, 2005.

[17] T. Thelaidjia, A. Moussaoui, dan S. Chenikher, "Feature Extraction and Optimized Support Vector Machine for Severity Fault Diagnosis in Ball Bearing," Engineering Solid Mechanics, vol. 4, no. 4, pp. 167-176, 2016.

[18] H. H. Ullu, T. Prahasto, dan A. Widodo, "Prognosis Kerusakan Bantalan Gelinding dengan menggunakan Metode Support Vector Regression (SVR)," Masters thesis Diponegoro University, Semarang, 2013.

[16] A. Widodo, "Application of Intelligent System for Machine Fault Diagnosis and Prognosis," Badan Penerbit Universitas Diponegoro, Semarang, 2019.

[17] A. Winoto, "Prediksi Umur Pahat Dengan Metode Mesin Pendukung (Support Vector Machine)," Teknik Mesin Fakultas Teknik Universitas Sebelas Maret, Surakarta, 2011.

[18] M. L. D. Wong, C. Liu, dan A. K. Nandi, "Classification of Ball Bearing Faults using Entropic Measures," Proceeding Surveillance 7, Chartres, France, 2014. 